\title{
Colonies of Northern Fulmars and Black-legged Kittiwakes Associated with the Northeast Water Polynya, Northeast Greenland
}

\author{
KNUD FALK ${ }^{1}$ AND SØREN MØLLER ${ }^{2}$
}

\author{
(Received 19 October 1994; accepted in revised form 6 March 1995)
}

\begin{abstract}
The first census of cliff-nesting seabirds dependent on the resources of the Northeast Water polynya was carried out in 1993. We made direct counts in six known colonies of the northern fulmar (Fulmarus glacialis) and used a combination of direct and photo counts in one colony of black-legged kittiwakes (Rissa tridactyla). Glaucous gulls (Larus hyperboreus) occurring at these colonies were also surveyed. A total of 1887 apparently occupied fulmar sites were counted, and a subjective attempt to correct for missed sites gave a total of 2550 apparently occupied sites, in which an estimated 1475 pairs laid eggs. The cliffs at Mallemukfjeld and a neighbouring unnamed cliff held $80 \%$ of the fulmar sites. Kittiwakes nested only at Mallemukfjeld, which held 873 apparently occupied sites in which an estimated 733 pairs initiated laying. The minimum glaucous gull population present in the six fulmar colonies was estimated at 22 occupied sites. The fulmar and kittiwake colonies at the Northeast Water polynya were larger than previously assumed. We present estimates based on daily variation in colony attendance of the effort required to detect annual differences in population size. There is now a basis for evaluating any future population changes in some of the most extreme high-arctic seabird populations.
\end{abstract}

Key words: northern fulmar, Fulmarus glacialis, black-legged kittiwake, Rissa tridactyla, seabirds, population monitoring, polynya, high Arctic, Greenland

RÉSUMÉ. On a effectué en 1993 le premier recensement des oiseaux marins nichant dans des falaises, qui dépendent des ressources de la polynie des eaux du Nord-Est. On a fait un comptage direct dans six colonies connues de fulmars boréaux (Fulmarus glacialis) et utilisé une combinaison de comptage direct et photographique dans une colonie de mouettes tridactyles (Rissa tridactyla). On a aussi relevé les goélands bourgmestres (Larus hyperboreus) présents dans ces colonies. On a compté un total de 1887 sites de fulmars apparemment occupés, et obtenu, en faisant une correction subjective pour les sites manqués, un total de 2550 sites apparemment occupés, où l'on estime que 1475 paires avaient pondu des oeufs. Les falaises de Mallemukfjeld et une falaise voisine innomée contenaient $80 \mathrm{p}$. cent des sites de fulmars. Les mouettes nichaient seulement à Mallemukfjeld, où se trouvaient 873 sites apparemment occupés dans lesquels on estime que 733 paires avaient commencé à pondre. La population minimale de goélands bourgmestres présente dans les six colonies de fulmars a été estimée à 22 sites occupés. Les colonies de fulmars et de mouettes de la polynie des eaux du Nord-Est étaient plus importantes qu'on l'avait supposé. On présente des estimations de l'effort requis pour détecter les différences annuelles de population, d'après les variations quotidiennes de présence dans les colonies. Il existe maintenant une base permettant d'évaluer tout changement futur de population dans certaines des populations les plus reculées d'oiseaux marins de l'Extrême-Arctique.

Mots clés: fulmar boréal, Fulmarus glacialis, mouette tridactyle, Rissa tridactyla, oiseaux marins, surveillance de la population, polynie, Extrême-Arctique, Groenland

Traduit pour la revue Arctic par Nésida Loyer.

\section{INTRODUCTION}

Seabirds need access to foraging areas at sea, which limits their distribution in the Arctic where ice cover is dense. As a consequence, high-arctic seabird colonies are always situated near ice edges, recurring leads or polynyas (Brown and Nettleship, 1981; Massom, 1988). The "Danmark Expedition" to northeast Greenland in 1906-08 rediscovered the Northeast Water polynya (Inuit had lived in the area previously) and located one of the world's most extreme higharctic seabird colonies, Mallemukfjeld, occupied by northern fulmars (Fulmarus glacialis) and black-legged kittiwakes (Rissa tridactyla) (Manniche, 1910). In 1939, Pedersen(1942) identified two more distinct fulmar colonies near the polynya. However, these pioneers in the area gave only vague references to population size. The most recent published information came from short visits by geologists to most of the fulmar colonies and other sites in 1980 and 1985 (Hjort et al., 1983, 1988). They reported a total of five fulmar colonies, but pointed out that no kittiwakes were observed at the cliffs.

As part of an international research programme studying physical and biological processes in the polynya (Anony-

\footnotetext{
${ }^{1}$ Zoological Museum, University of Copenhagen, 15 Universitetsparken, DK-1200 Copenhagen $\emptyset$, Denmark; present address: Ornis Consult, Vesterbrogade 140, DK-1620, Copenhagen V, Denmark

${ }^{2}$ Roskilde University, P.O. Box 258, DK-4000, Roskilde, Denmark

(C) The Arctic Institute of North America
} 
mous, 1989), we performed the first quantitative survey of the cliff-nesting seabird species along the Northeast Water in 1993. On the basis of detailed observations of the species breeding at Mallemukfjeld, we estimate total numbers of breeders and non-breeders occupying the fulmar and kittiwake colonies near the polynya and provide a basis for assessing future population changes. Since the variation in numbers of birds in the colony has implications for population monitoring, data on diel and seasonal variation in nest site attendance are presented as well. In addition, the colour phase distribution of the northern fulmar population is described. Details of fulmar and kittiwake breeding ecology in the area will be presented elsewhere.

\section{METHODS}

\section{Study Area}

Field work was carried out along the coast of Holm Land and Amdrup Land (Fig. 1). Glaciers cover most of the land area, but at the eastern part of Holm Land and at Kap Jungersen at Amdrup Land the late Palaeozoic limestone and sandstone sedimentary rocks (Escher and Watt, 1976) are exposed as $350-500 \mathrm{~m}$ high cliffs and talus slopes. The icefree land areas along the coast are extremely barren, with less than $1 \%$ vegetation cover.

The study area is situated at the edge of the Northeast Water (NEW) polynya. Small areas and leads of open water are present all year round, but in average years the 'summer polynya' forms gradually in spring from about 15 May, reaches its maximum extent by the end of August, and closes again by rapid ice formation in mid September. At most, the polynya reaches from Nordostrundingen at $82^{\circ} \mathrm{N}$ to $77^{\circ} \mathrm{N}$, and covers an area of about $25000 \mathrm{~km}^{2}$ (as in 1993), but typically the open water area does not exceed $17000 \mathrm{~km}^{2}$ (Pedersen et al., 1993; Gudmandsen et al., 1993, in press).

\section{Fulmar Census}

The census of northern fulmars was performed during the laying and incubation period, when the number of birds attending the colony was at a high level (Hatch, 1989). From vantage points along the top of the cliffs, sectors of the colonies along concave stretches of coastline could be overlooked. From each protruding point we counted all visible birds, and positions where birds were sitting (= "apparently occupied sites"; Nettleship, 1976). We made no attempt to distinguish between sites occupied by brooding birds and non-breeding prospectors.

Some cliff face areas and ledges were hidden by outcrops and overhangs. At each distinct section of the cliff, the observers subjectively judged the proportions of cliff face and ledges that were out of view, giving a crude correction factor to estimate the total population. Hence, the actual recorded number gives the minimum population size, and the corrected figure a "best estimate." At convex portions of the

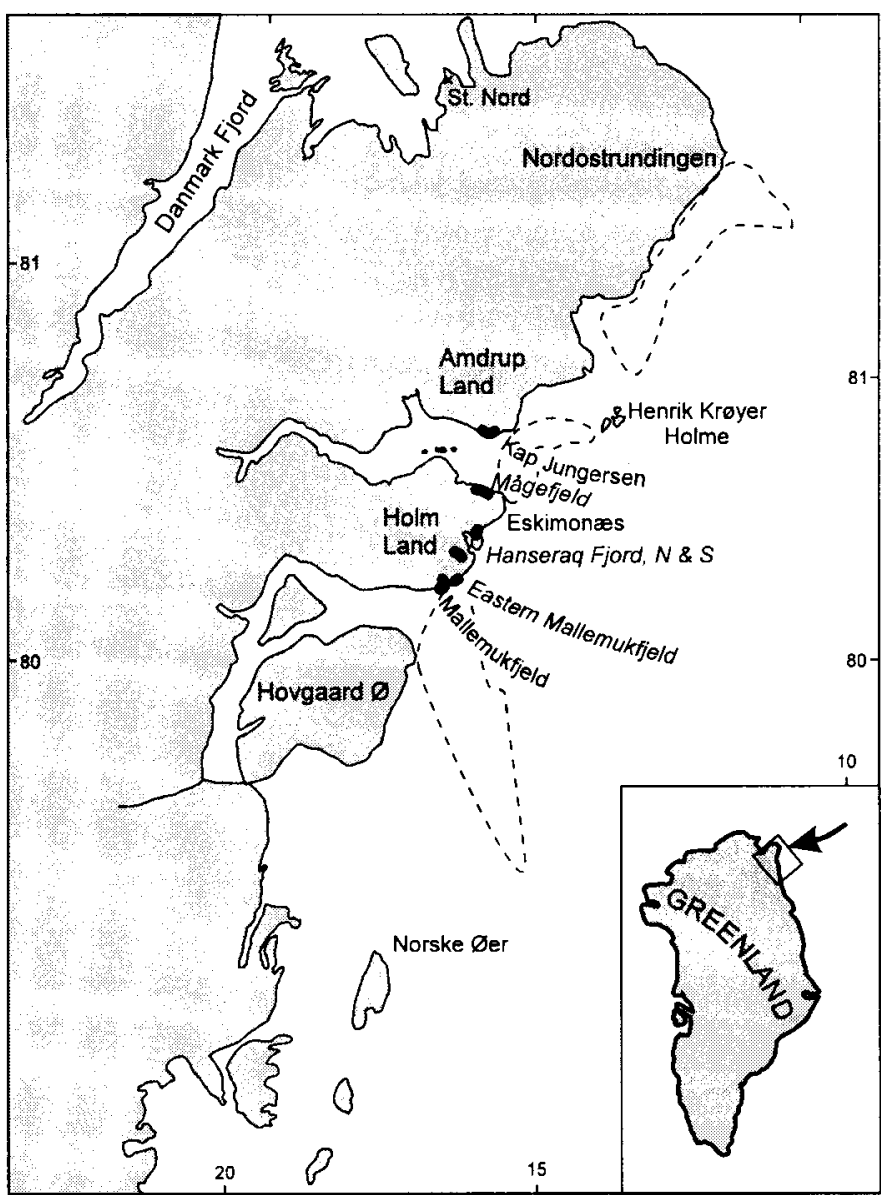

FIG. 1. Map of northern fulmar colonies (black marks at the coast, and names in italics) in Northeast Greenland along the Northeast Water polynya (exemplified by the dashed lines indicating approximate limits of open water as seen on a NOAA satellite image from 27 May 1993).

coastline, the cliff face could not be inspected, but from the traffic of arriving and departing birds it was obvious that those parts of the cliffs only held few birds (with some exceptions, see below). At Mallemukfjeld the cliffs were also inspected from below, either from the coastline and ice edge or from an inflatable boat. Although fulmar sites could not be counted from below, cliff sections with birds could be identified, and these inspections confirmed that at Mallemukfjeld very few fulmars frequented the convex cliff sections that could not be seen from above.

Two of the colonies, Hanseraq Fjord North and Mågefjeld, could not be surveyed from cliff edges, but were counted from a Bell 206 helicopter slowly passing the cliffs twice at a distance of about $100 \mathrm{~m}$. At Eastern Mallemukfjeld the number of sites on one convex section was roughly estimated during a single helicopter pass, while one section of Kap Jungersen remained unsurveyed.

During field work between 15 May and 8 August at the largest colony at Mallemukfjeld $\left(80^{\circ} 11^{\prime} \mathrm{N}, 16^{\circ} 38^{\prime} \mathrm{W}\right)$, we daily counted the number of birds present in eight fulmar (and one kittiwake) study plots (Fig. 2) with known numbers of breeding sites (sites occupied by pairs that laid an egg). A correction factor $(\mathrm{k},=$ number of breeding pairs per bird 
present) was calculated and applied to the census data to estimate total breeding populations.

The number of birds present in the designated study plots was also used to describe seasonal and daily variation in colony attendance of both species, and to establish a baseline for identifying future population changes. Occasionally fog prevented counting birds at some plots, but in the data analysis missed plots were prorated from their average contribution to daily totals (Hatch, 1989). To measure diel variation in attendance, we counted fulmars in plot L (Fig. 2) and the ledges below every hour, and kittiwakes every second hour (see dates in Fig. 5).
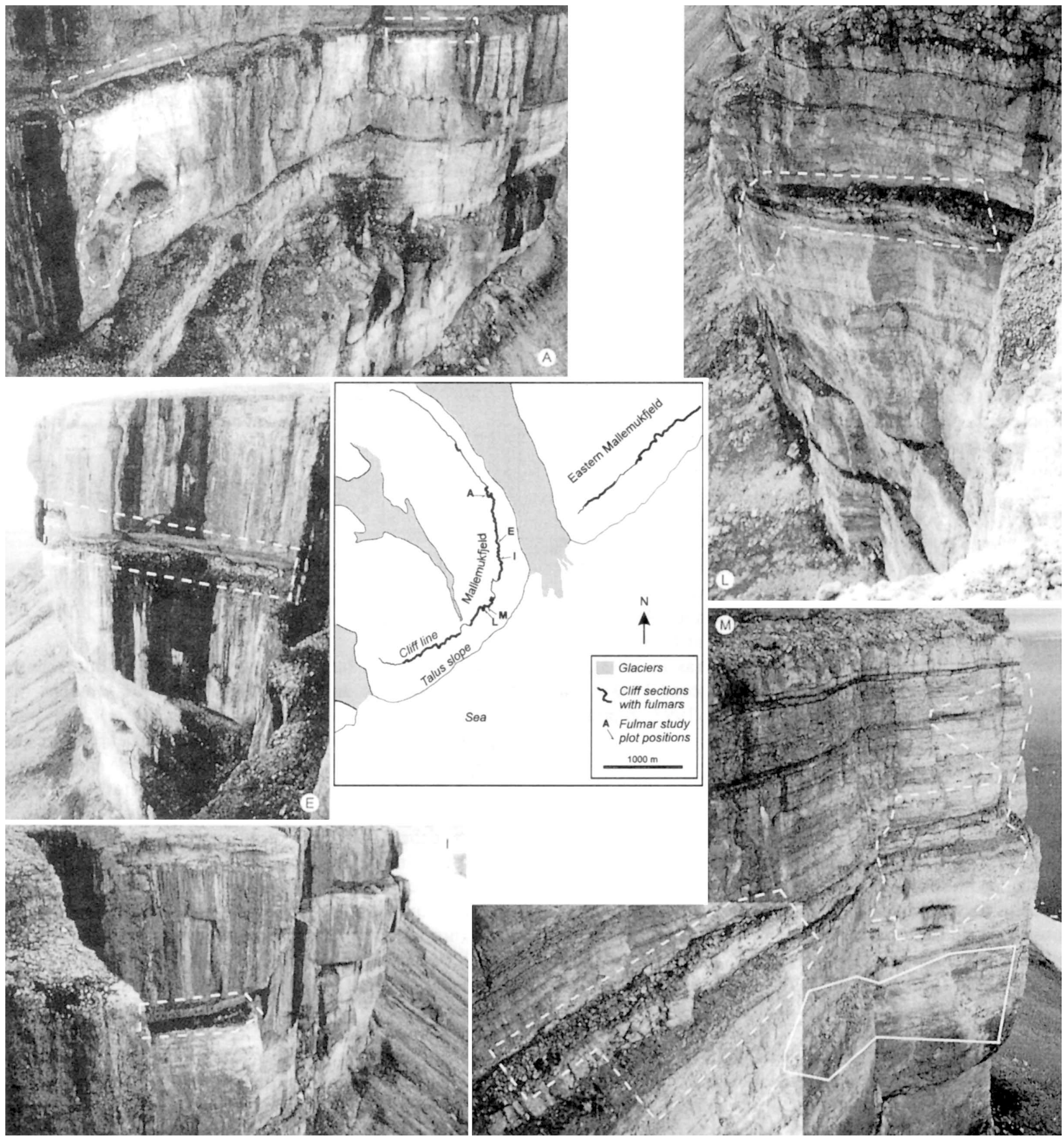

FIG. 2. Location and delineation of eight fulmar study plots (dashed lines) and one kittiwake study plot (solid line) on Mallemukfjeld; only the quantitative plots used in this study are given. 


\section{Fulmar Colour Phases}

Colour phases of the fulmars were recorded at the main colony at Mallemukfjeld. At six sectors of the colony, all sitting birds were inspected through a $20 \times$ telescope and assigned to one of the colour phase classes LL (double-light), L (light), D (dark) or DD (double-dark) defined by Fisher (1952) and refined by van Franeker and Wattel (1982). The appearance of the birds' plumage varied considerably with light conditions, and the colour phases were therefore determined only on overcast days, when we considered light most neutral for the purpose.

\section{Black-legged Kittiwake Census}

Parts of the kittiwake colony were counted from two vantage points. In one study plot, holding approximately $11 \%$ of the population, the birds were counted daily, and the number of nests was counted in late egg to early chick stage (Nettleship, 1976; Harris, 1987). From observations in that study plot, the proportion of pairs laying at least one egg was also determined.

Most kittiwakes nested on parts of the cliff not visible from above, and these sections were counted as "number of sites with birds" from projected $24 \times 36$ slides (Ektachrome 100) taken on two occasions: first, on 26 June (egg stage) with a $400 \mathrm{~mm}$ telephoto lens from an inflatable boat approximately $400 \mathrm{~m}$ from the cliff, and second, on 5 July with a $105 \mathrm{~mm}$ telephoto lens from a BO 105 helicopter slowly approaching and passing the colony. Previous observations at the study plot had indicated that gradually approaching helicopters did not cause panic among the kittiwakes on the cliff. On the slides, only sites with one or two birds were counted and considered equivalent to an occupied nest, because unattended nests could not be reliably identified on the background of the light limestone rocks.

\section{Glaucous Gull Census}

The glaucous gull (Larus hyperboreus) population was counted while conducting the fulmar survey. We recorded freshly built nests and defensive pairs.

\section{RESULTS}

\section{Fulmar Population}

The northern fulmars were breeding at six colonies at the edge of the Northeast Water (Fig. 1). The northernmost colony was at Kap Jungersen on Amdrup Land and the remaining five on the eastern coast of Holm Land down to the southernmost colony at Mallemukfjeld (Table 1). Some of the colonies were situated near each other, but for convenience they are treated here as separate colonies. We recognize Mallemukfjeld and the neighbouring Eastern Mallemukfjeld (no official name) as separate colonies although they have
TABLE 1. Number of apparently occupied sites, and number of individuals at six northern fulmar colonies in Northeast Greenland.

\begin{tabular}{llrrrrrrr}
\hline \hline & \multirow{2}{*}{$\begin{array}{l}\text { Survey } \\
\text { Colony }\end{array}$} & \multicolumn{2}{c}{ Observed \# of } & & \multicolumn{3}{c}{ Estimated \# of } \\
\cline { 3 - 4 } \cline { 6 - 8 } & date & Sites & Birds & & Sites & Birds & Pairs $^{2}$ \\
\hline Mallemukfjeld & June-July & 1141 & 1310 & & 1350 & 1550 & 775 \\
East. Mallemukfjeld & June 06 & 351 & 405 & & 725 & 850 & 425 \\
Hanseraq Fjord, S & June 13 & 132 & 155 & & 175 & 200 & 100 \\
Hanseraq Fjord, N & July 24 & 45 & & & 50 & 50 & 25 \\
Mågefjeld & July 24 & 110 & & & 100 & 125 & 50 \\
Kap Jungersen & July 05 & 108 & 127 & & 150 & 175 & 100 \\
Total & & 1887 & 1997 & & 2550 & 2950 & 1475 \\
\hline \hline
\end{tabular}

${ }^{1}$ Figures rounded to nearest 25.

${ }^{2}$ Calculated from estimated number of birds by a k-factor of 0.50 (see Results).

been treated together by previous visitors to the area.

The total of 1887 apparently occupied sites holding 1997 individuals (Table 1) represents the minimum population size. By applying correction factors for the estimated proportions of breeding sites not visible during the survey, the total population may be estimated at 2550 apparently occupied sites.

From eight study plots (Fig. 2) containing a total of 101 breeding pairs (egg laid) at Mallemukfjeld, the mean k-value (number of breeding pairs per bird present) for the period 1 June to 15 July ( $\mathrm{n}=45$ days) was $0.50(\mathrm{SD}=0.04)$. Applying this factor to the total number of birds estimated on the six colonies gives an active breeding population of 1453-1485 pairs (95\% confidence limit). This estimate does not include a cliff section at Kap Jungersen where the traffic of flying birds suggested that fulmar sites were also present on ledges invisible from the cliff edge and not assessed from the helicopter. That section may have held an additional 20-100 sites.

Mallemukfjeld $\left(80^{\circ} 11^{\prime} \mathrm{N}, 16^{\circ} 38^{\prime} \mathrm{W}\right)$ and neighbouring Eastern Mallemukfjeld $\left(80^{\circ} 12^{\prime} \mathrm{N}, 16^{\circ} 31^{\prime} \mathrm{W}\right)$ hold about $52 \%$ and $28 \%$, respectively, of the estimated population of fulmars along the polynya. These cliffs provide special physical conditions for nesting: impressive $140 \mathrm{~m}$ high, flat-topped limestone cliffs with about $200 \mathrm{~m}$ of talus sloping to sea level (Fig. 3). At the vertical (slight overhang) cliff face are three storeys of ledges from one to three metres deep, and almost all fulmars nest on these ledges, which offer shelter from a substantial overhang. Most nests are situated on southeastfacing cliff sections overlooking the sea, but at Mallemukfjeld birds nest up to $2 \mathrm{~km}$ inland on east-facing cliffs above a glacier (map in Fig. 2). Pedersen (1942: Fig. 18) indicated that fulmars were also breeding just west of Mallemukfjeld (west of the western glacier), but we did not observe any birds on this part of the coastline, where there are only small cliffs.

Hanseraq Fjord South $\left(80^{\circ} 16^{\prime} \mathrm{N}, 16^{\circ} 41^{\prime} \mathrm{W}\right)$ is a small colony where the nests are thinly distributed over approximately $2 \mathrm{~km}$ of low cliff facing NNE. The cliff is very eroded, and there is a long slope of loose scree and gravel from the plateau above the colony to the edge, but the indented cliff edge allows views to most of the fulmar sites. 


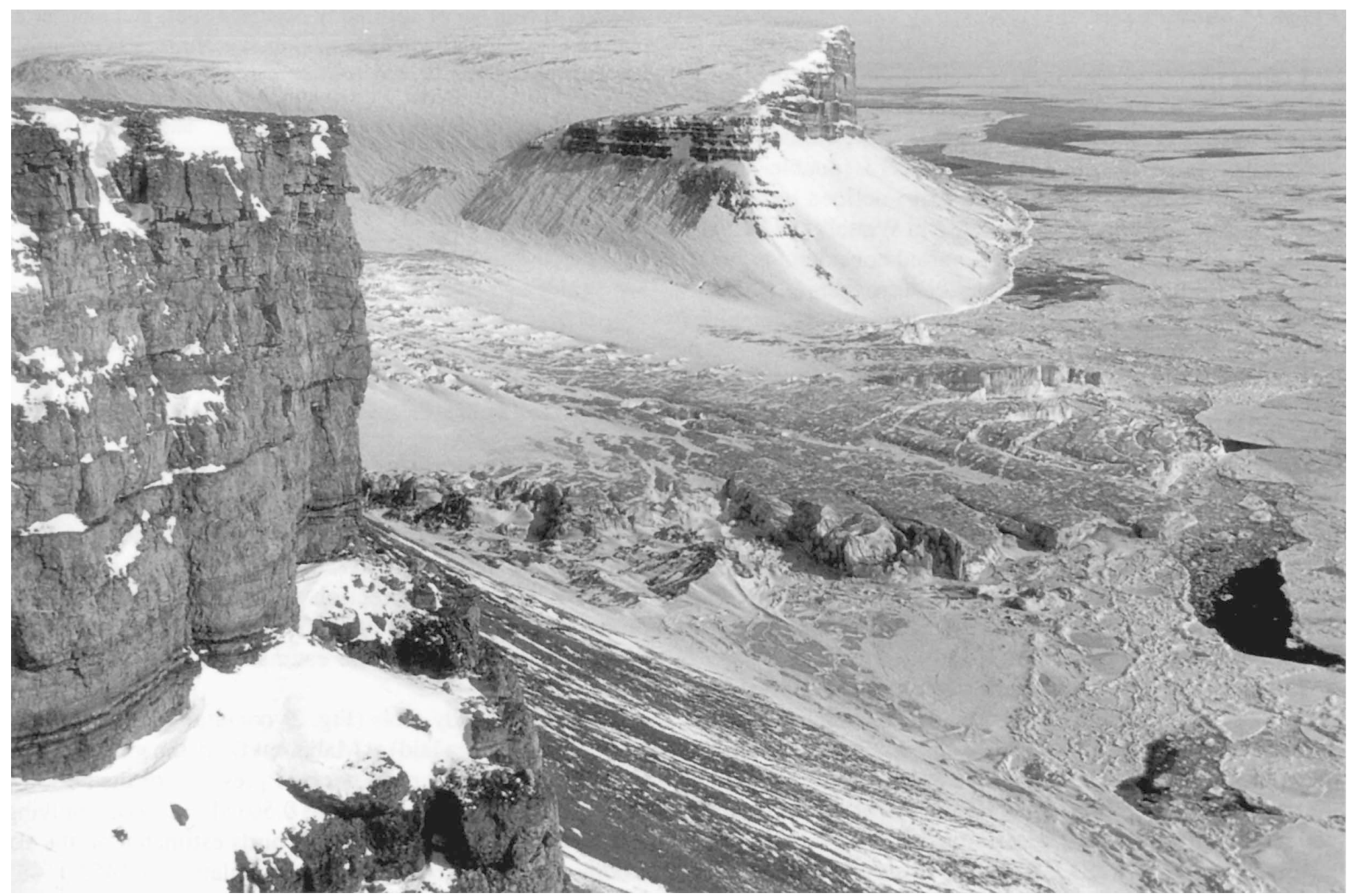

FIG. 3. Two of the northern fulmar breeding cliffs in Northeast Greenland: the flat-topped limestone cliffs of Mallemukfjeld (front) and neighbouring Eastern Mallemukfjeld (across the glacier, photo of 21 May 1993).

Hanseraq Fjord North $\left(80^{\circ} 20^{\prime} \mathrm{N}, 16^{\circ} 14^{\prime} \mathrm{W}\right)$ is the smallest colony. All sites were at the vertical east-facing section, and most of the 45 sites recorded were located at a single long ledge. The colony cannot be surveyed from the cliff edge.

Mågefjeld $\left(80^{\circ} 27^{\prime} \mathrm{N}, 16^{\circ} 12^{\prime} \mathrm{W}\right)$ at the entrance to Ingolf Fjord is a north-facing low cliff with a huge slope of gravel down to the cliff edge. Most fulmar sites are located low at the vertical part of the cliff. The colony cannot be surveyed from above, nor can the sites be seen from below.

Kap Jungersen $\left(80^{\circ} 37^{\prime} \mathrm{N}, 16^{\circ} 10^{\prime} \mathrm{W}\right)$ is a south-facing cliff line that is very indented, and vantage points allow good views of many sections with fulmar sites. But one low-lying section on the cape is invisible from above and probably holds some fulmar sites not quantified in this study; if these sites could have been counted, Kap Jungersen would probably be the third largest fulmar colony at the Northeast Water. Disregarding the unsurveyed section, almost the entire colony was found along approximately $2 \mathrm{~km}$ of cliff line west of the peak of Kap Jungersen; only a group of six sites was located east of the peak.

Breeding sites in all colonies were situated at inaccessible ledges, well protected from the potential mammalian predators in the area, arctic fox (Alopex lagopus), ermine (Mustela erminea) and polar bear (Ursus maritimus).

\section{Colour Phases}

The northern fulmar population breeding at the NEW polynya showed all colour shades from the white LL to the darkest grey, DD; the majority was assigned to phase D (Table 2). The ratio between light $(\mathrm{LL}+\mathrm{L})$ and dark $(\mathrm{D}+\mathrm{DD})$ was $12: 88$, and $97.8 \%$ of the birds may be termed "coloured" (= L, D, DD) (van Franeker and Wattel, 1982).

There was great variation within the D-category. Some birds were light grey on the crown, nape, throat and breast, but had very dark upper wings and back, while others were nearly uniformly light to dark grey without falling into the DD category. Also, some very light birds had traces of grey on the crown and nape or sides of breast, making them borderline cases of phase L/LL (van Franeker and Wattel, 1982).

\section{Kittiwake Population}

Kittiwakes bred only at Mallemukfjeld where they nested on narrow ledges unsuitable for fulmars. Combining direct counts and photo counts, the total kittiwake population was 873 apparently occupied sites. Of 94 nests in the study plot, eggs were laid in $79(84 \%)$. Applying this correction factor to the total number of sites counted, an estimated 733 pairs of 
kittiwakes initiated breeding in the colony during 1993.

\section{Glaucous Gull Population}

The population of glaucous gulls was very small; in total we recorded only 22 pairs at five of the fulmar colonies surveyed. Most pairs (13) were found at Mallemukfjeld, four at Kap Jungersen, three at Mågefjeld, one each at Hanseraq Fjord North and Eastern Mallemukfjeld. However, at Mallemukfjeld we once witnessed 16 birds scared out from the lower parts of a large cliff invisible from above, and a number of pairs may have been overlooked here as well as on other cliffs.

TABLE 2. Numbers and proportions of colour phases of northern fulmars nesting at Mallemukfjeld, Northeast Greenland.

\begin{tabular}{lcc}
\hline \hline Colour phase $^{1}$ & Number observed & Proportion $(\%)$ \\
\hline LL & 10 & 2.2 \\
L & 45 & 9.8 \\
D & 373 & 81.3 \\
DD & 31 & 6.8 \\
\hline \hline
\end{tabular}

${ }^{1}$ as in Fisher (1952), refined by van Franeker and Wattel (1982).

\section{Colony Attendance}

The number of birds attending the colony varied over the breeding season. In the kittiwake colony, major fluctuations occurred when the birds occupied their sites in the spring, and levelled off from about the time laying began at 12 June (Fig. 4). Fulmar numbers peaked shortly after the median laying date (31 May) and, despite marked fluctuations, tended to decrease gradually until a sharp drop occurred from the last days of July (Fig. 4). For population monitoring purposes, repeated counts within 50 days from the first laying date have been proposed for the black-legged kittiwake (Hatch and Hatch, 1988). At Mallemukfjeld, the mean number of kittiwakes present at the study plot during the egg stage (first egg laid 12 June) was $103.3(\mathrm{SD}=8.7)$ as indicated by the dashed line in Figure 4. Similarly, in the eight fulmar study plots, a mean of $203.2(\mathrm{SD}=17.4)$ birds was recorded during the main egg period between 1 June and 15 July ( $n=45$ days). Regression of the number of birds against day during the proposed census periods was not significant for the kittiwake (slope 0.02 birds $\cdot$ day $^{-1}, p=0.83$ ), but was significantly negative for the fulmar (slope -0.82 birds $^{*} \mathrm{day}^{-1}, p=0.0001$ ).

None of the species showed any clear diel variation in colony attendance in the continuous daylight (Fig. 5).

\section{DISCUSSION}

The population survey and estimates showed that the northern fulmar colonies in Northeast Greenland are substantially larger than previous information had suggested. The first record (1907) from the area stated that "the Fulmars were

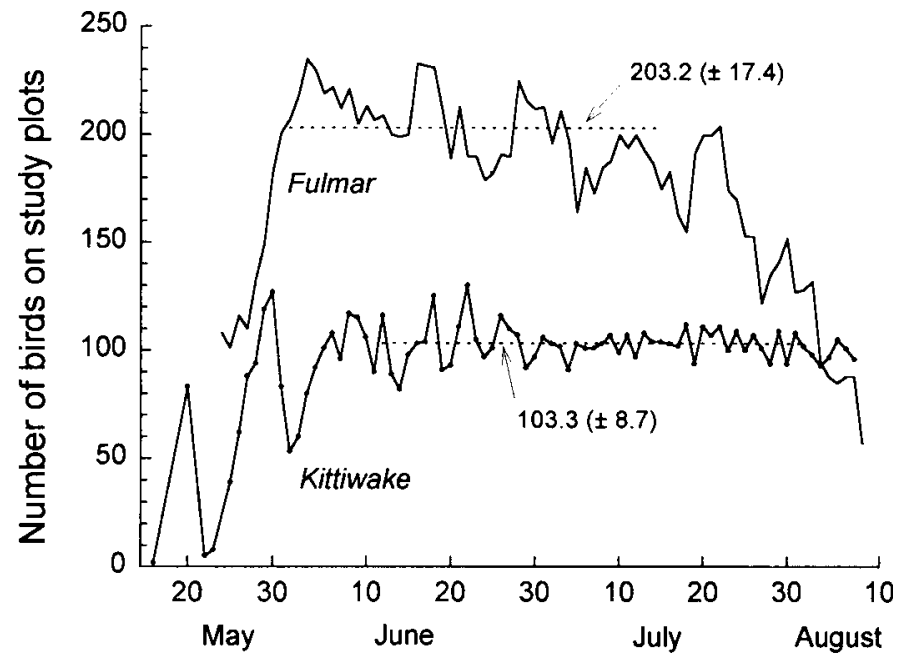

FIG. 4. Colony attendance of fulmars and kittiwakes on study plots at Mallemukfjeld, 1993; dashed lines indicate means during the proposed census periods (see text).

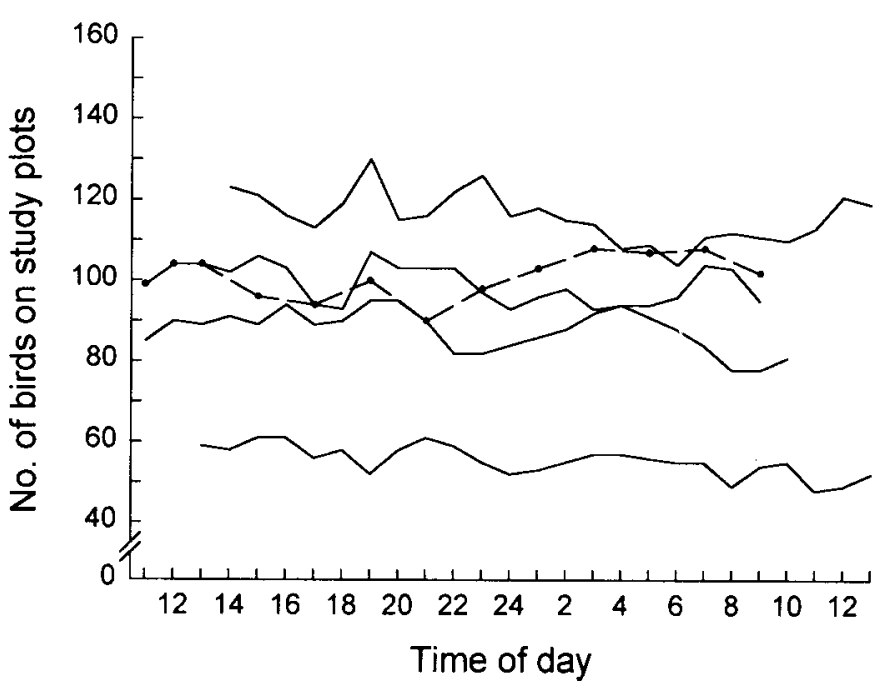

FIG. 5. Colony attendance during full-day counts in one kittiwake study plot (dashed line with symbols, July 15-16) and selected fulmar plots (solid lines, from top to bottom: June 4-5, June 25-26, July 15-16, and August 5-6).

present in greater numbers - by hundreds but not by thousands" (Manniche, 1910:123), and in 1939 "hundreds" of fulmars were seen circling around the cliffs at Kap Jungersen (Pedersen, 1942:72). In 1980, Hjort et al. (1983) noted approximately 250 birds at Mallemukfjeld and up to 50 birds at each of the four small colonies. We directly counted 2000 birds at nesting ledges in 1993, and comparing this count to the old information one could suspect a population increase during this century. Nevertheless, the difference is more likely caused by different survey procedures. Except for visits in 1980, all observations must have been made from the sea ice below the cliffs where the breeding sites on the deep ledges are not visible; the early observers could record mainly the traffic of flying birds high up at the $400 \mathrm{~m}$ tall cliffs.

There is, however, one observation suggesting that the northern fulmar has expanded its range in Northeast Greenland: a new colony of approximately 150 individuals was 
established between 1964 (and most likely after 1976) and 1987 at Hvalros $\varnothing$, about $630 \mathrm{~km}$ south of Mallemukfjeld (Stemmerik, 1990). This colony is near a small coastal polynya.

The nearest neighbouring fulmar colonies to the Northeast Water are at Spitsbergen, $560 \mathrm{~km}$ to the east. According to the most recent information, the known fulmar population (some colonies have not been quantified recently) of Spitsbergen (excluding Bear Island) may be at least 35000 pairs (F. Mehlum, Norwegian Polar Institute, pers. comm. 1994). In Greenland, the fulmar breeding sites are few and largely confined to West Greenland, and apart from the new colony at Hvalrosø mentioned above, the only other East Greenland fulmar colonies are situated near Scoresby Sound around $70^{\circ} \mathrm{N}$ (Salomonsen, 1950).

Manniche (1910) mentioned that black-legged kittiwakes were breeding at Mallemukfjeld and other cliffs between $80^{\circ} 10^{\prime}$ and $80^{\circ} 20^{\prime}$. On modern updated maps this area corresponds to the coastline from west of Mallemukfjeld to just north of Hanseraq Fjord, but in 1993 the kittiwake was found breeding only at Mallemukfjeld, and none at all were observed during the visits to other seabird cliffs at the Northeast Water. Regarding population size, "some 100 individuals" were counted here on 9-10 June 1907, "it is however probable, that a greater number were nesting on these places" (Manniche, 1910:163). The colony could very well have been of the same size in 1907 as today, and there is no basis for assuming any significant population change over the 86 years that have passed since the colony was first discovered. But the kittiwake has recently established a small colony (8 pairs in 1989 , ca. 15 pairs in 1993) near Danmarkshavn, about $390 \mathrm{~km}$ south of Mallemukfjeld (Boertmann, 1994; J. Graugaard, pers. comm. 1994). The nearest neighbouring major kittiwake colonies are situated at Spitsbergen, where the most recent available data indicate a population of roughly 200000 pairs (F. Mehlum, pers. comm. 1994).

It is puzzling that no kittiwakes at all were observed at Mallemukfjeld in 1980 (Hjort et al., 1983). It cannot be ruled out that the colony at Mallemukfjeld was simply overlooked during the brief visit on 11 July, as the colony is not very easily recognized from above unless the observers negotiate certain uninviting vantage points. However, from other areas it is well known that in years with unfavourable conditions kittiwake breeding can fail completely, and although failed breeders stay at or near the colonies, attendance may be erratic (Kampp, 1984; Birkhead and Nettleship, 1988; Murphy et al., 1991; Hatch et al., 1993), reducing the chance of detecting the presence of a small population. The teams of geologists compiling the information presented by Hjort et al. (1983) spent almost two months in various areas along the Northeast Water, and only two individuals were recorded from a research vessel at the eastern edge of the polynya in 1980 (Hjort et al., 1987). By contrast, up to 18 kittiwakes per hour passed by Eskimonæs in late July 1993 (C. Hjort, unpubl. data) and they were seen daily in all parts of the polynya from the research vessels Polarstern and Polar Sea operating in the Northeast Water throughout the summer. In fact, the polynya opened up later in 1980 than in average years, whereas in 1993 the ice breakup was normal and during the summer the polynya became larger than usual (Pedersen et al., 1993; Gudmandsen et al., 1993, in press). Thus, conditions may have been particularly favourable for the seabirds, allowing for high breeding success and colony attendance in 1993. It is possible that under poor conditions, for example in years of late ice breakup, the kittiwakes may avoid this extreme high-arctic area and not attend their usual breeding sites at the Northeast Water.

The glaucous gull is not restricted to a few breeding sites as are the other two species, but is known to inhabit a number of small colonies in most of Northeast Greenland (Manniche, 1910; Pedersen, 1942) where it probably relies mainly on marine food sources in leads and local polynyas. A similar distribution pattern has been found in high-arctic regions of eastern Canada (Nettleship, 1974b; Brown and Nettleship, 1981). In the Northeast Water where the glaucous gull breeds in association with the fulmar and kittiwake, we have seen that these species contribute considerably to the glaucous gull's diet (mainly eggs and chicks but also injured and dead adults).

The first quantitative study of northern fulmars and blacklegged kittiwakes along the Northeast Water has established a base for assessing future changes in populations associated with the polynya. Detection of population changes or fluctuations is especially interesting in the high Arctic where the species occur at the extreme limits of their range. Remote sensing and climate models suggest that the effects of climate change may be amplified and thus detectable sooner at high latitudes (Massom, 1991; Chapin, 1992), and probably the distribution and numbers of arctic seabirds would be affected (Brown, 1991). Of course, population changes may not be caused by climate alone; the boreal fulmar in the Atlantic has undergone a substantial population increase and expansion of its breeding range over the last centuries. But the arctic populations are considered not to have undergone a similar change, and recent discoveries of major fulmar breeding sites in the Canadian Arctic were considered results of increased survey intensity, not of a population increase (Fisher, 1952; Salomonsen, 1965; Nettleship, 1974a, b). The northern fulmar colonization of Northeast Greenland is not recent: fulmar bones were excavated in 1993 from old Inuit camp sites at Eskimonæs at the edge of the polynya. Preliminary archaeological dating suggests that the fulmars were hunted by settlers in the area 2800-2300 years ago. Fulmar bones have also been recovered from 300 to 500 year old Thule culture sites at the Northeast Water polynya, along with bones of king eiders (Somateria spectabilis), ivory gulls (Pagophila eburnea) and unidentified large gulls (C. Andreasen, University of Greenland, pers. comm. 1994).

The seabirds can be used as important marine indicators in connection with monitoring programmes. Population fluctuations and trends can be detected in kittiwake populations relatively soon after a change in the marine environment (Chapdelaine and Brousseau, 1989), and according to Hatch and Hatch (1988), the mean number of birds in study plots 
during egg and early chick stage is a reliable observation unit for assessing population changes in this species. Because breeding success and attendance patterns can vary considerably between different parts of a colony, however, it is recommended for monitoring purposes to define many (randomly chosen) study plots instead of a few plots that may not be representative for the colony (Harris, 1987; Hatch and Hatch, 1988). But conditions at Mallemukfjeld allowed designation of only one plot comprising approximately $11 \%$ of the entire kittiwake colony, that may serve as a reference for future evaluation of population change and breeding success. Among the northern fulmars at Mallemukfjeld eight study plots were designated, altogether holding nearly $7 \%$ of the estimated breeding population in the Northeast Water (Fig. 2).

For future visits to the area, it may be valuable to know how many individual counts (observation days) of birds in attendance in the study plots would be necessary to detect a certain change in the seabird populations. Disregarding for this purpose any potential spatial variation within the colony, the number of counts required during the egg-stage can be calculated from the observed variation in number of birds recorded in study plots (Wanless et al., 1982; Hatch and Hatch, 1988). With the observed variation in kittiwake attendance, only five counts will be sufficient to detect a change of $27 \%$ between years at Mallemukfjeld, with $95 \%$ confidence of finding a significant difference between means at the 0.05 significance level, while 11 counts would detect a $15 \%$ change, and 22 counts a $10 \%$ change (Fig. 6). Even as many as $34-50$ counts will only detect a change of $6.5 \%$ to $8 \%$ with the specified confidence and probability. As stated by Hatch and Hatch (1988:618), "greater sensitivity using present techniques is precluded by the inherent variability among daily counts."

Because of the greater variation in fulmar numbers (Fig. 4), population monitoring by counts of birds at the study plots will be less accurate than for the kittiwake. With the variation observed in the fulmar attendance between 1 June and 15 July, 13 counts (days) would be required to detect a $27 \%$ change between years with the same confidence and prob-

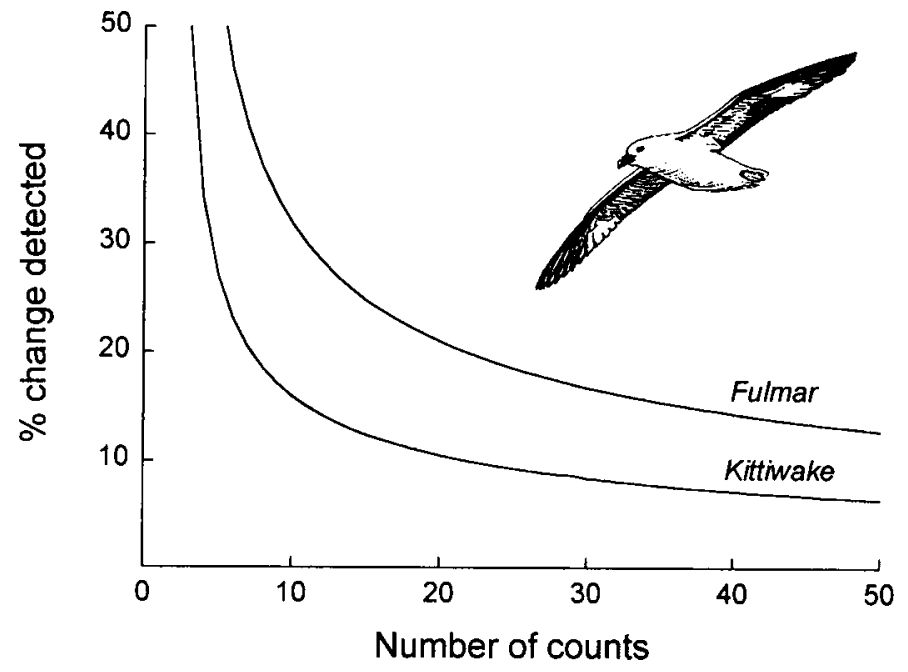

FIG. 6. Number of counts (on different days) required to detect a certain population change between years with $95 \%$ confidence of finding a significant difference between means at the 0.05 significance level.

ability as specified above for the kittiwake (Fig. 6). As many as 22 counts would detect a $20 \%$ change and, at best, counts at all 45 days would detect only changes of at least $14 \%$. Because variation in attendance is less in the early part of the breeding season, counts performed only during June may give slightly more accurate estimates than the same number of counts dispersed over the entire egg-stage. Judged from the 1993 data, population counts can be performed at any time of the day, since none of the species showed any clear diel rythm in attendance. As a reference for future surveys, the weekly statistics on plot counts of both species are given in Table 3 .

The colour phases of the birds could appear very different in changing light and at different angles. Hence, the figures for proportions of colour phases in the population may only be considered an approximate figure. This will always be the case when assigning categories to the non-discrete polymorphism in the Atlantic populations of the northern fulmar. The colour phase distribution in the Northeast Greenland population is very similar to that reported from west

TABLE 3. Weekly statistics on total numbers of northern fulmars and black-legged kittiwakes present in designated study plots ${ }^{1}$ at Mallemukfjeld in 1993.

\begin{tabular}{|c|c|c|c|c|c|c|c|c|c|c|}
\hline \multirow{2}{*}{$\begin{array}{l}\text { Period } \\
\text { (week) }\end{array}$} & \multicolumn{5}{|c|}{ Northern Fulmar } & \multicolumn{5}{|c|}{ Black-legged Kittiwake } \\
\hline & Mean & $( \pm 95 \%$ C.L. $)$ & Min & Max & $\mathrm{N}^{2}$ & Mean & $( \pm 95 \%$ C.L. $)$ & Min & Max & $\mathrm{N}$ \\
\hline May 25 - 31 & 141.4 & $( \pm 35.1)$ & 101 & 201 & 7 & 109.7 & $( \pm 58.2)$ & 83 & 127 & 3 \\
\hline Jun $01-07$ & 220.6 & $( \pm 8.9)$ & 207 & 235 & 7 & 84.3 & $( \pm 19.3)$ & 53 & 108 & 7 \\
\hline Jun $08-14$ & 207.7 & $( \pm 7.1)$ & 199 & 221 & 7 & 102.1 & $( \pm 13.7)$ & 82 & 117 & 7 \\
\hline Jun $15-21$ & 215.6 & $( \pm 16.0)$ & 189 & 233 & 7 & 103.6 & $( \pm 10.8)$ & 91 & 125 & 7 \\
\hline Jun $22-28$ & 192.4 & $( \pm 14.0)$ & 179 & 225 & 7 & 109.4 & $( \pm 10.1)$ & 97 & 130 & 7 \\
\hline Jun $29-05$ Jul & 201.1 & $( \pm 16.8)$ & 164 & 215 & 7 & 99.1 & $( \pm 5.4)$ & 91 & 106 & 7 \\
\hline Jul $06-12$ & 189.3 & $( \pm 8.9)$ & 173 & 200 & 7 & 102.1 & $( \pm 3.5)$ & 97 & 107 & 7 \\
\hline Jul $13-19$ & 178.3 & $( \pm 13.6)$ & 155 & 193 & 7 & 103.9 & $( \pm 5.1)$ & 94 & 112 & 7 \\
\hline Jul $20-26$ & 179.1 & $( \pm 20.6)$ & 153 & 204 & 7 & 106.4 & $( \pm 4.3)$ & 100 & 111 & 7 \\
\hline Jul $27-02$ Aug & 133.9 & $( \pm 9.3)$ & 122 & 152 & 7 & 100.8 & $( \pm 7.0)$ & 94 & 109 & 6 \\
\hline Aug $03-08$ & 83.5 & $( \pm 14.1)$ & 57 & 95 & 6 & 97.5 & $( \pm 5.0)$ & 93 & 105 & 6 \\
\hline
\end{tabular}

${ }^{1}$ Data on northern fulmar combined from the 8 plots defined in Fig. 2.

${ }^{2}$ Number of days counted 
Spitsbergen - as correctly surmised by van Franeker and Wattel (1982)—where the proportion of LL:L:D:DD phases in a sample of 5352 birds was 0.2:5.0:85.1:9.7 (Pennycuick and Webbe, 1959). The main difference between the two populations seems to be an even smaller share of LL birds $(0.2 \%$ versus $2.2 \%)$ in the Spitsbergen population than in Northeast Greenland.

In summary, the Northeast Water holds a considerably larger population of northern fulmars and black-legged kittiwakes than previously known or suspected, and there is now established a basis for assessing future changes in the higharctic seabird populations associated with the polynya.

\section{ACKNOWLEDGEMENTS}

This study was a part of NEWland-a contribution to the Northeast Water Polynya Project of the International Arctic Polynya Programme (Arctic Oceans Sciences Board). The seabird ecology research was funded by The Carlsberg Foundation, Danish Natural Sciences Research Council and The Commission for Scientific Research in Greenland. The NEWland program was coordinated by the Danish Polar Centre, Copenhagen, and the Swedish Polar Research Secretariat, Stockholm. NEWland's logistics were funded by The Commission for Scientific Research in Greenland, the Swedish Polar Research Secretariat, Aa. W. Jensen's Foundations, and the Ole M. Wiinstedt Foundation. We are grateful to Claus Andreasen, University of Greenland, Nuuk, and Peter Gravlund, Zoological Museum, Copenhagen, for allowing us to use yet unpublished information on archaeology in Northeast Greenland, and to Fridtjof Mehlum, Norwegian Polar Institute, for information on seabirds in Spitsbergen. We thank the scientific coordinators and crew on the research vessels Polarstern and Polar Sea as well as the Geological Survey of Greenland for continuous support and for allocating helicopter time to complete the seabird survey and transfer the field team. The Danish Defence Ministry and the staff of Station Nord are thanked for their hospitality and effective assistance. Hauge Anderson, Danish Polar Centre, provided excellent logistic planning during all phases of the field work. We thank Christian Hjort and two anonymous referees for their valuable comments on early versions of this paper.

\section{REFERENCES}

ANONYMOUS, ed. 1989. International Arctic Polynya Program (IAPP). (A program of the Arctic Oceans Sciences Board.) Fairbanks: Institute of Marine Sciences, University of Alaska. 27 p.

BIRKHEAD, T.R., and NETTLESHIP, D.N. 1988. Breeding performance of Black-legged Kittiwakes, Rissa tridactyla, at a small, expanding colony in Labrador. Canadian Field-Naturalist 102:20-24.

BOERTMANN, D. 1994. An annotated checklist to the birds of Greenland. Meddelelser om Grønland Bioscience 38:1-63.

BROWN, R.G.B. 1991. Marine birds and climatic warming in the northwest Atlantic. Canadian Wildlife Service Occasional Paper 69:49-54.
BROWN, R.G.B., and NETTLESHIP, D.N. 1981. The biological significance of polynyas to arctic colonial seabirds. Canadian Wildlife Service Occasional Paper 45:59-65.

CHAPDELAINE, G., and BROUSSEAU, P. 1989. Size and trends of Black-legged Kittiwake (Rissa tridactyla) populations in the Gulf of St. Lawrence (Quebec) 1974-1985. American Birds 43:21-24.

CHAPIN, F.S., III, ed. 1992. Arctic ecosystems in a changing climate. London: Academic Press. 449 p.

ESCHER, A., and WATT, W.S., eds. 1976. Geology of Greenland. Copenhagen: The Geological Survey of Greenland. 603 p.

FISHER, J. 1952. The Fulmar. London: Collins.

GUDMANDSEN, P., PEDERSEN, L.T., SKRIVER, H., THOMSEN, B.B., and MINNETT, P. 1993. Radar observations of an arctic polynya under summer conditions. Proceedings of the Second ERS-1 Symposium - Space at the Service of our Environment, Hamburg, Germany, 11-14 October 1993. ESA SP-361.

GUDMANDSEN, P., THOMSEN, B.B., PEDERSEN, L.T., and MINNETT, P. In press. North-East Water polynya satellite observations - summer 1992 and 1993. International Journal of Remote Sensing.

HARRIS, M.P. 1987. A low-input method of monitoring Kittiwake Rissa tridactyla breeding success. Biological Conservation 41: $1-10$.

HATCH, S.A. 1989. Diurnal and seasonal patterns of colony attendance in the Northern Fulmar, Fulmarus glacialis, in Alaska. Canadian Field-Naturalist 103:248-260.

HATCH, S.A., and HATCH, M.A. 1988. Colony attendance and population monitoring of Black-legged Kittiwakes on the Semidi Islands, Alaska. Condor 90:613-620.

HATCH, S.A., BYRD, G.V., IRONS, D.B., and HUNT, G.L., Jr. 1993. Status and ecology of kittiwakes (Rissa tridactyla and $R$. brevirostris) in the North Pacific. In: Vermeer, K., Briggs, K.T., Morgan, K.H., and Siegel-Causey, D., eds. The status, ecology, and conservation of marine birds of the North Pacific. Canadian Wildlife Service Special Publication. Ottawa: Canadian Wildlife Service. $140-153$.

HJORT, C., HÅKANSSON, E., and STEMMERIK, L. 1983. Bird observations around the Nordøstvandet polynya, Northeast Greenland, 1980. Dansk Ornitologisk Forenings Tidsskrift 77:107-114.

HJORT, C., EDELSTAM, C., and MEHLUM, F. 1987. Fågel- och däggdjurstaxeringer i Polarhavet. In: Hoppe, G., BjörnRasmussen, S., and Roland, M.W., eds. Expeditionen Ymer80 - en slutrapport. Stockholm: Kungliga Vetenskapsakademien. 151-156.

HJORT, C., HÅKANSSON, E., and MØLGAARD, P. 1988. Bird observations on Kilen, northeasternmost Greenland, 1985. Dansk Ornitologisk Forenings Tidsskrift 82:19-24.

KAMPP, K. 1984. Lomvierne i Disko Bugt og Uummannaaq Fjord. Copenhagen: Zoologisk Museum.

MANNICHE, A.L.V. 1910. The terrestrial mammals and birds of North-east Greenland. Meddelelser om Grønland 45:1-200.

MASSOM, R.A. 1988. The biological significance of open water within sea ice covers of the polar regions. Endeavour 12:21-27. 
1991. Satellite remote sensing of polar regions. London: Belhaven Press. 307 p.

MURPHY,E.C., SPRINGER, A.M., and ROSENEAU, D.G. 1991. High annual variability in reproductive success of kittiwakes (Rissa tridactyla L.) at a colony in western Alaska. Journal of Animal Ecology 60:515-534.

NETTLESHIP, D.N. 1974a. Northern Fulmar colonies on the south coast of Devon Island, N.W.T., Canada. The Auk 91:412.

. 1974b. Seabird colonies and distributions around Devon Island and vicinity. Arctic 27:95-103.

1976. Census techniques for seabirds of arctic and eastern Canada. Canadian Wildlife Service Occasional Paper 25. 31 p.

PEDERSEN, A. 1942. Säugetiere und Vögel. Meddelelser om Grønland 128:1-119.

PEDERSEN, L.T., GUDMANDSEN, P., and SKRIVER, H. 1993. North-East Water: A remote sensing study. Unpubl. report. Available at Remote Sensing Unit, Electromagnetic Institute, Technical University of Denmark, Lyngby, Denmark. 65 p.
PENNYCUICK, C.J., and WEBBE, D. 1959. Observations on the Fulmar in Spitsbergen. British Birds 52:321-332.

SALOMONSEN, F. 1950. Grønlands fugle. (The Birds of Greenland). Copenhagen: Munksgaard. 608 p.

. 1965. The geographical variation in the Fulmar (Fulmarus glacialis) and the zones of marine environments in the North Atlantic. The Auk 82:327-355.

STEMMERIK, L. 1990. Hvalros $\varnothing$ - en ny ynglelokalitet for Mallemuk Fulmarus glacialis og muligvis Søkonge Alle alle i det nordlige Østgrønland. Dansk Ornitologisk Forenings Tidsskrift 84:161.

VAN FRANEKER, J.A., and WATTEL, J. 1982. Geographical variation of the Fulmar Fulmarus glacialis in the North Atlantic. Ardea 70:31-44.

WANLESS, S., FRENCH, D.D., HARRIS, M.P., and LANGSLOW, D.R. 1982. Detection of annual changes in the numbers of cliffnesting seabirds in Orkney, 1976-80. Journal of Animal Ecology 51:785-795. 